\title{
La recepció del teatre espanyol a Catalunya. Un cas d'estudi: El último mono (1926) de Carlos Arniches i la seva adaptació catalana (L'adroguer del carrer Nou, 1929)
}

\author{
The reception of the Spanish theatre in Catalonia. \\ A case study: Carlos Arniches' El último mono (1926) \\ and its Catalan adaptation (L'adroguer del carrer Nou, 1929)
}

\author{
Veronica Orazi \\ Università degli Studi di Torino \\ veronica.orazi@unito.it
}

\begin{abstract}
Study of the reception of Carlos Arniches' play El último mono in Catalonia, through the analysis of its Catalan translation. Starting from the identification of the characteristic features of the author's theatre, as presented in the work under examination, the strategy of transposition into the resulting hypertext will be defined, according to the different types of treatment (preservation, adaptation, replacement, elimination, etc.) of the key elements, both in terms of content as well as of language and style.
\end{abstract}

Keywords: Carlos Arniches' theatre, El ultimo mono, reception of Spanish theatre in Catalonia, theatrical adaptation, hypertextuality

\section{INTRODUCCIÓ}

L'any 1926 Carlos Arniches (Alacant 1866 - Madrid 1943) publica El último mono o El chico de la tienda, sainet en tres actes que s'estrena al Teatro del Centro de Madrid el 10 de novembre del mateix any (Arniches, 1926; Díez-Canedo, 1926). El 1929 la peça és adaptada al català per Antoni Pejoan, amb el títol L'adroguer del 
carrer Nou, estrenada al Teatre Talia de Barcelona el 13 de desembre del mateix any i publicada en La Escena Catalana al desembre de 1930 (Arniches, 1930; Gallén, 2001, p. 62). A partir d'aquest cas d'estudi, s'analitzarà la recepció de l'obra d'Arniches a Catalunya, a través de l'enfocament dels trets característics del teatre de l'autor, segons com es concreten en la peça examinada, i se n'identificarà l'estratègia de transposició en l'hipertext derivat, segons les tipologies de tractament dels seus elements constitutius, tant pel que fa al contingut com al llenguatge i estil.

En la seva trajectòria de dramaturg, Arniches produeix durant cinquanta-cinc anys més de seixanta peces i un centenar d'obres en collaboració. Es dedica al género chico, que neix com a reacció contra la sarsuela gran i l'opereta d'origen estranger i connecta amb una tradició costumista genuïnament hispànica, representada pels $\mathrm{Pa}$ sos i Entremeses de Lope de Rueda, Cervantes, Quiñones de Benavente i els sainets de Ramón de la Cruz (Montero Padilla, 2010, p. 19); el seu començament s'identifica convencionalment amb Cuadros al fresco (1870) de Tomás Luceño i el seu apogeu coincideix amb els anys 1890-1900; finalment, la seva extinció s'estableix al voltant del 1910.

Arniches concreta la superació de la fórmula dramatúrgica realista o costumista, com ara la dels germans Álvarez Quintero o bé les dels epígons Martínez Sierra o Linares Rivas (Ruiz Ramón, 2011, p. 48) i cultiva diferents gèneres teatrals, com ara les diverses modalitats del género chico, la sarsuela, el sainet, la revista, la farsa, el juguete cómico, la comèdia rural i costumista, adreçades a un públic majoritari, tot i que no necessàriament popular. És un autor sensible a l'expectació del públic i dels empresaris que demanen un teatre d'entreteniment, que satisfà amb una producció aparentment senzilla. El seu teatre es caracteritza per la presència de situacions i tipus estereotipats (el fresco, el xulo, el guàrdia municipal), un final feliç, tot un repertori de mecanismes i elements còmics (acudits, jocs verbals, equívocs) i la inclusió de cantables. És un expert creador de diàlegs, capaç de combinar eficaçment humor, melodrama i sentit comú i aconsegueix sintetitzar l'acció i l'esquema argumental i crear un equilibri amb els cantables.

El seu teatre -especialment el de la primera època- es relaciona amb el Madrid del seu temps, on l'alacantí es muda a començament de 1885. Allí estrena la seva primera peça, la revista Casa editorial en collaboració amb Gonzalo Cantó, el 9 de febrer de 1888 al Teatro Eslava de Madrid. Les obres successives s'emmarquen en les diferents tipologies del género chico i sintetitzen tipus i esquemes dramàtics que esdevenen paradigmàtics. El 1899 estrena La cara de Dios, "drama de costumbres populares", la seva primera peça en tres actes, amb moments melodramàtics i fulletonescos però també escenes còmiques i musicals, tendència que seguirà desenvolupant i que culminarà en La chica del gato (1921). Entre els anys 1903 i 1912 collabora amb Enrique García Álvarez, amb qui escriu vodevils, sarsueles còmiques i sainets, però també un melodrama moral (Alma de Dios, de 1907). El 1915-1916 publica una sèrie de sainetes rápidos que recollirà en el volum Del Madrid castizo (Monleón, 
1966, p. 49), en el pròleg del qual subratlla que en ells tot "debe ser como el medio social que refleja: pobre, sencillo, oscuro" (Arniches, 2010, p. 51).

Durant la seva nova etapa compon peces de major envergadura, caracteritzades per una certa depuració dramatúrgica i l'aproximació progressiva a la tragèdia grotesca, que desenvolupa en parallel amb les modalitats anteriors, un canvi apreciat per la crítica (Pérez de Ayala, 1966, p. 321-338, 498-512) que marca la seva maduresa i representa la seva fase més brillant. Arniches construeix la seva tragèdia grotesca a partir d'antinòmies: la fatalitat transforma el covard en heroi, el tímid en atrevit, el ximple en espavilat, però sempre des d'una perspectiva caricaturesca amb ressonàncies chaplinianes. En els sainets (molts dels quals en tres actes i definits com a alargados) redueix l'element de teatralitat popular i costumista (com passa amb El último mono o El chico de la tienda) i simplifica el component melodramàtic; escriu La señorita de Trevélez (1916, que considera una "farsa cómica" on, tot i així, apareixen la tristesa i l'amargor), ‘Que viene mi marido! (1918, la primera que l'autor defineix com a tragèdia grotesca) i Es mi hombre (1921), que vehiculen una certa crítica social (Paco, 1994), relacionada amb el Regeracionisme de l'època. El canvi de públic l'inclinarà cap a la comèdia burgesa i atenuarà l'element crític (Sotomayor Sáez, 1998). Quan esclata la Guerra Civil torna a Alacant, on escriu El Padre Pitillo, obra que es pot considerar la síntesi del seu teatre, caracteritzat pel costumisme saineter, els elements picarescos i melodramàtics, l'ambientació realista, els diàlegs còmics, la lluita contra les adversitats, l'esperit crític i el sentit comú, així com el missatge final moralitzador i esperançat. El 8 de desembre de 1936 s'embarca cap a Buenos Aires i comença una gira per Argentina i Uruguai; el 1940 torna a Espanya, a Madrid. La seva última peça, Don Verdades, es representa el 1943, poc després de la seva mort.

L'estructura i les característiques del teatre d'Arniches han estat estudiades des de fa temps per la crítica (Portillo, 1948; Lentzen, 1966; Monleón, 1966; Ramos, 1966; Ríos Carratalá, 2003; Ríos Carratalà, 2006a; Ríos Carratalà, 2006b; Ríos Carratalá, 2008). El component lingüístic i estilístic també va cridar l'atenció d'alguns estudiosos (López Estrada, 1943; Lentzen, 1966, p. 185-201; Senabre, 1967; Seco, 1970): el realisme escènic es concreta també i especialment a través del seu realisme lingüístic que, tanmateix, no és exclusivament mimètic, sinó que presenta una sorprenent riquesa verbal. El dramaturg capta el llenguatge popular madrileny i realitza un procés creatiu personalíssim, una mena d'“arnichesació" de la llengua que juga un paper clau en la seva dramatúrgia. De fet, el llenguatge popular dels personatges s'allunya de la realitat i es perfila com un argot fruit de la creació de l'autor, amplificat per girs, expressions i termes populars (Fernández Almagro, 1948, p. 221-223). Es tracta d'un llenguatge elaborat que mai no perd la seva versemblança tot i que es projecta més enllà del mimetisme lingüístic, aconseguit aprofitant una tècnica personal i eficaç. Com que el seu objectiu no és incorporar al seu teatre la realitat històrica, l'autor no ofereix la reproducció fotogràfica de l'ambient i del llenguatge madrilenys, sinó creacions absolutament originals, purament teatrals i voluntàriament elaborades. 


\section{EL ÚLTIMO MONO O EL CHICO DE LA TIENDA}

Pedro Salinas (1949, p. 135) havia afirmat que el "juego de comicidad externa y gravedad profunda [...] construye la esencia misma de [la] segunda etapa del arte de Arniches", reflexió aplicable a aquest sainet en tres actes i reafirmada per Ruiz Ramón (2011, p. 43). Vilches de Frutos i Dougherty ho expliquen amb més precisió:

El único sainete que consiguió recabar cierto éxito durante estos años [1926-1931] fue El último mono o El chico de la tienda, [...] (Centro, 10-XI-1926, 98 r.), cuyos tres actos presentan la historia de cómo el chico del título (Bibiano) salva al dueño de una [...] tienda de comestibles (el señor Nemesio) de la mala pasada que le juegan "aquellos que más gratitud le debían" $(A B C)$. El sainete fue bien recibido por la crítica que aplaudió el acierto de Arniches -"conoce como pocos la manera de llegar al público y domina con insuperable gracia el diálogo y la composición de los tipos" $(A B C)$-, la construcción melodramática del enredo (La Época y La Libertad) [...] y la maestría del autor a la hora de "acometer todos los ripios sainetescos-melodramáticos que hay" y hacer de ellos "un sainete de los clásicos de Loreto Prado" ( $E l S o l)$. El corte tradicional de la pieza -"se trata de una pieza verdaderametne antigua" ( $\mathrm{La} \mathrm{Voz}$ ) - no fue señalado como defecto en este caso; antes bien figuró entre los atractivos de la obra, según el crítico de El Liberal: “Acaso gran parte de la simpatía que despertaron en los espectadores los personajes del sainete estrenado se debe a que son viejos amigos nuestros todos ellos. ${ }^{1}$ (1997, p. 109)

En la peça, per tant, disminueix el component costumista, se simplifica l'element melodramàtic i es crea un protagonista, Bibiano, amb ressonàncies chaplinianes. Aquest personatge és ingenu, bonhomiós, generós i entranyable i això emfatitza el seu potencial melodramàtic: és un jove humil, menyspreat i sempre maltractat, que gairebé no aconsegueix defensar-se, protegit tan sols per la filla del propietari de la botiga on treballa. S'enamora de la seva protectora i acaba salvant-la a ella, el seu pare i el negoci familiar d'una estafa ordida pel xicot d'aquesta i la xicota del seu pare, que són amants. El protagonista no imita Chaplin o els personatges chaplinians, sinó que reflecteix d'alguna manera aquest tipus, a causa de la influència del que ja havia esdevingut un mite cinematogràfic. Això explica el gran èxit de la peça, que es va representar fins a l'esclat de la Guerra Civil.

En l'obra -com en tota la producció del dramaturg-el llenguatge juga un paper clau, amb la seva gran riquesa i força teatral, que la dinamitza i en suporta la comicitat (Lentzen, 1966, p. 185-201; Senabre, 1967). Senabre identifica l'originalitat del llenguatge de l'autor -que no és "la mera reproducción de la jerga barriobajera madrileña" (1966, p. 248)- amb la "dislocación expresiva", és a dir "la deformación intencionada de vocablos y expresiones con fines humorísticos" (1966, p. 266). L’estudiós alludeix

${ }^{1}$ Les citacions es refereixen a les següents ressenyes: Floridor (1926) a l'ABC, M. F. A. (1926) a $L a$ Época, Villa (1926) a La Libertad, Larios de Medrano (1926) a El Liberal, Díez-Canedo (1926) a El Sol i Mayral (1926) a $L a$ Voz. 
a la "deformación de préstamos y adopciones lingüísticas" i al "convencionalismo": fer parlar els personatges com si fossin gent del poble, però a partir d'un model de popularisme allunyat de la realitat i antimimètic: mentre el saineter casticista transcriu la jerga que escolta, Arniches crea el seu propi sistema lingüístic, aprofitant paraules, girs i expressions populars que deforma per plasmar el seu personal llenguatge popular. Es tracta, per tant, d'una actitud que no és mimètica, sinó creativa. Tot i així, i tenint en compte la profunda originalitat lingüística de l'autor, el madrileñismo es confirma com l'element bàsic del género chico i també d'una (bona) part de la seva producció: cal analitzar, llavors, com s'adapta això al context català.

\section{L'ADROGUER DEL CARRER NOU}

Se sap poquíssim d'Antoni Pejoan (1884-?), l'adaptador de l'hipotext, que es va representar en català amb el títol L'adroguer del carrer Nou el 13 de desembre de 1929 al Teatre Talia de Barcelona i es va publicar en La Escena Catalana el desembre de 1930. Precedentment, Prudenci Bertrana havia publicat una crítica de l'estrena de la versió original en castellà, El último mono, a La Veu de Catalunya, que va aparèixer en l'edició del vespre del 14 de gener de 1927: segons sembla, aquest sainet formava part del repertori dels teatres amateurs barcelonins i, si considerem que l'adaptació catalana va ser publicada en una collecció popular, és possible que Antoni Pejoan procedís d'aquell món.

L'hipertext ofereix una mostra de les tècniques transposicionals i de les dificultats i eleccions que l'adaptador ha de fer a l'hora d'enfrontar-se a qualsevol text i especialment a un text com aquest. La versió catalana preserva les peculiaritats creadores de l'autor, que són treballades de forma igualment peculiar. Es tracta de processos deformants de caràcter fonètic, morfològic i semàntic, que afecten paraules, locucions i sintagmes i que produeixen la destrucció dels esquemes establerts, tret típic del llenguatge arnichesco (Senabre, 1967, p. 275).

\subsection{ELEMENTS PARATEXTUALS}

El títol de l'hipertext s'adapta al context d'arribada: l'atenció es manté en la figura del protagonista, un jove aprenent d'adroguer, feble i temerós que, finalment, es torna un atrevit $i$ actua salvant la situació. A això s'afegeix una dada inèdita, també relacionada amb els receptors de l'adaptació, és a dir la referència al carrer de Barcelona on es troba la botiga: la calle de Argumosa de l'hipotext és substituïda pel carrer Nou, emblemàtic de la Barcelona popular de l'època. En l'edició original, després del llistat dels personatges, l'hipotext precisa "La acción en Madrid, actualmente" mentre que en l'hipertext es llegeix “L'acció a Barcelona. Ėpoca actual”. Aquest ele- 
ment aproxima l'ambient on es desenvolupa l'acció al públic local i propicia la seva identificació amb el context de la història (Bacardí, 2010, p. 5). És a dir, la primera operació de transposició realitzada per l'adaptador és la introducció de topònims urbans característics de l'ambit de recepció específic en els elements paratextuals clau (títol i acotació inicial).

De la mateixa manera, també els antropònims són adaptats, com resulta del Repartiment:

\begin{tabular}{|l|l|}
\hline \multicolumn{1}{|c|}{ El último mono, reparto } & \multicolumn{1}{|c|}{ L'adroguer del carrer Nou, repartiment } \\
\hline el señor Nemesio & El senyor Quim \\
su hija Maravillas & la seva filla Esperanceta \\
Leoncio, dependiente y novio de Maravillas & Enric \\
parroquiana: una señorita elegante (cupletista) & parroquiana: la senyoreta Elena \\
Lauro, dependiente & Manel \\
Sisinio, dependiente & Papitu \\
el señor Liborio & el senyor Llibori \\
Asunción, pareja de Nemesio & Teresina \\
Bibiano, el chico de la tienda & Patufa \\
el señor Carballo (prestamista) & el senyor Raspall \\
la señá Patro (ex-novia de Nemesio) & la senyora Munda \\
Cirila (criada) & Quiteria \\
\hline
\end{tabular}

Aquesta pràctica segueix la mateixa línia del tractament dels topònims i es fa servir per apropar la peça, els seus continguts i el seu missatge als nous espectadors (Bacardí, 2010, p. 5).

\subsection{TRACTAMENT DE LA PARLA MADRILENYA}

En l'hipotext la parla madrilenya apareix ja en el repartiment i perfila d'entrada la seva connotació lingüística i l'origen geogràfic i social dels personatges. El madrilenyisme de l'original es caracteritza pels vulgarismes que, en el cas dels vulgarismes fonètics, paralitzen la creativitat del dramaturg que ha de reflectir la parla callejera aprofitant l'ortografia convencional (Senabre, 1967, p. 250-251). De fet, abunden els trets vulgars, com ara els desplaçaments accentuals, monoftongacions i diftongacions, epèntesis, paragoges i epítesis (Senabre, 1967, p. 250-253); també les creacions lèxiques, com ara substantius postverbals, formes superlatives o femenines o plurals, paraules compostes o derivades (per sufixació) i parasíntesi (Senabre, 1967, p. 253-265).

És aquest el primer gran repte a l'hora d'adaptar l'hipotext. L'adaptador, teòricament, té dues opcions: la primera és tractar d'identificar una varietat diatòpica i diastràtica si no equivalent almenys assimilable (des de la perspectiva cronològica, espacial i social), com ara -per posar tan sols un exemple- el parlar xava, difós al 
començament del s. XX als barris obrers de Barcelona, que es reflecteix també en l'àmbit literari, com per exemple en la novella La Xava (1910) de Juli Valmitjana. És evident que aquesta hipòtesi no és viable, per la seva dificultat i, especialment, artificiositat. Queda, doncs, la segona possibilitat, que generalment s'aprofita en casos com el que ens ocupa: l'eliminació d'aquesta connotació lingüística, tot i que resulti fins i tot consubstancial a l'obra original i, amb la seva desaparició, es perdi un component fonamental de l'hipotext. En aquest cas, però, Pejoan compensa parcialment aquesta situació mantenint prou castellanismes, escrits entre cometes. Això representa un dels trets clau de l'operació realitzada, perquè és quelcom que es fa possible gràcies a l'àmbit específic de recepció, que permet aquesta estratègia pel bilingüisme que el caracteritza. En l'hipertext, per tant, es mantenen formes com ara "buenas" (salutació), "piropo", "pedidos", "apuro", "mono", "melena", etc.

Tanmateix existeix un altre mecanisme clau de l'hipotext que es manté a l'hipertext, que Senabre (1967, p. 265) defineix com a "dislocación expresiva". Això es concreta en la deformació de paraules cultes, tant a nivell fonètic o semàntic o bé per ennobliment o etimologia popular i, sobretot, en la deformació de préstecs i adopcions lingüístiques i de locucions (Senabre, 1967, p. 265-276). Aquest mecanisme de deformació sistemàtica produeix un efecte humorístic i fins i tot còmic, que l'adaptador treballa de manera eficaç.

\subsection{EFECTISME HUMORÍSTIC}

\subsection{1. ÚS DE DIMINUTIUS}

En l'hipotext, un personatge s'expressa aprofitant constantment diminutius inoportuns que resulten humorístics, aspecte que es perd en la versió catalana. És el cas del señor Carballo, el prestador, que esdevé el senyor Raspall en la versió d'arribada:

a) "Pues nada, nada; lo resolveremos en seguidita" > "Res, res [...] ho podrem resoldre de seguida";

b) "Una temporadita de atención, un poquito de economía, institir en el cobro de atrasitos... [...] Y en seguidita a flote" > "Una temporadeta d'atenció, un xic d'economies, apretar a aquells que li deuen [...] I de seguida amunt, a surar";

c) "nada... una cosita breve, concreta, sencilla... pura formulita... ¡Pero si éste es un documentito que no tiene transcendencia!" > "res... una cosa breu, concreta, senzilla... pura fórmula... Si és un document que no té transcendència!"; etc.

Aquest aspecte s'extremitza fins al punt que la señorita Maravillas (Esperanceta en l'adaptació), impacientada pel fet que el prestador li lleva importància a la situació que en canvi és vital per a ella i el seu pare, li contesta imitant la seva forma de parlar, efecte que es perd en l'hipertext: "esos rengloncitos nos puén dejar en la callecita... ¡ya ve usté!" > "aquestes ratlles podran plantar-nos al mig del carrer". 


\subsubsection{MANTENIMENT DE FORMES DE L'HIPOTEXT (CASTELLANISMES)}

En l'hipertext els casos de manteniment de formes originals són emfatitzats gràficament; això és un tret decisiu, ja que pot funcionar tan sols en un context bilingüe on els espectadors entenen la barreja lingüística que permet preservar l'efecte humorístic de la conversa:

a) quan una de les parroquianes marxa i diu "Muy buenas", l'altra comenta "Eso de muy buenas no lo dirá usté por las lentejas que se lleva" > "Apa. Buenas" i l'altra "Això de buenas no ho dirà pas per les llenties que s'emporta";

b) la criada Cirila (Quiteria) tem que Bibiano (Patufa) no tindrà coratge d'actuar a l'hora d'impedir la traïció que estan ordint Leoncio (Enric) i la señá Asunción (Teresina) contra Nemesio (Quim); llavors, el noi li contesta que "usté desconfía porque sabe que soy aquí el último mono", mot que recorda el títol del sainet i que es manté en la versió catalana "Vostè desconfia perquè sap que aquí sóc l'últim mono"; a partir de l'ús de l'hispanisme mono s'origina un joc verbal, que queda inalterat en català: "l'últim mono sóc jo", "en tot cas, seria mona; és a dir, seria mona si no tingués aquesta cara...";

c) entra en escena el dependent Sisinio (Papitu), engalanat, ballant de forma ridícula i cantant "Charlestón, chalestón, es el baile que Charlot bailó en Bostón... Charlestón, charlestón, que es el baile que Charlot balió en Bostón..." -que es manté en castellà-; el noi anirà amb la seva núvia a ballar "en la Bombilla Danginggg" > "al Tropezón o a la Bombilla Dangingggg", on a més s'hi afegeix la referència a la dimensió local, introduint juntament al realia ${ }^{2}$ de l'hipotext un altre realia que remet a l'àmbit d'arribada de l'hipertext;

d) la señorita Maravillas (Esperanceta) li arregla el barret a Bibiano (Patufa); el noi es queda embadalit i, quan la criada Cirila (Quiteria) el sacseja per què torni a la realitat, aquest contesta que es quedarà durant quinze dies amb el posat que li agrada a la seva ama; llavors la criada exclama "iSe va a morir de hambre!” i Bibiano contesta "¿No me ha hecho dos bollos en el sombrero? ... Pues m'alimentaré con ellos" $>$ "Es morirà de gana!", "De gana, amb aquest parell de bollos que m'ha fet al barret? M'alimentaré de bollos", on el joc verbal es manté aprofitant el castellanisme, operació possibilitada, un cop més, pel bilingüisme dels receptors.

\subsubsection{ADAPTACIONS}

Al text d'arribada també hi apareixen casos d'adaptació, total o parcial, de formes i expressions de l'original.

${ }^{2}$ A propòsit del concepte de realia en traductologia, vegeu Osimo (2004, p. 63), així com Vlahof i Flori (2019). 


\subsubsection{Adaptacions totals}

a) Una parroquiana atractiva i prosperosa entra a la botiga; Nemesio (Quim), el propietari, la reconeix i comenta "la cocinera del ventiséis duplicado" i el senyor Liborio (Llibori) contesta "iya se le nota el duplicado!" > "és la cuinera del vint-i-sis bis", "ja se li veu que és doble";

b) després, Liborio recorda quan va obrir una botiga i, al poc de temps, la va haver de tancar perquè havia posat al rètol els seus cognoms i la gent no entrava: "Caro y Malo. Comestibles" > "Car i Dolent. Comestibles"; etc.

\subsubsection{Adaptacions parcials}

En alguns casos, en canvi, l'adaptació és parcial: Bibiano (Patufa) explica que ha comprat un xurro amb descompte, perquè a la tarda, els xurros que sobren, els liquiden amb un $25 \%$ de "buenificación", que pasa a "buenificació" (en ambdós textos entre cometes); etc.

\subsubsection{CANVIS/SUBSTITUCIONS}

També en la versió catalana hi ha exemples de canvis i/o substitucions, respecte a l'hipotext:

a) una parroquiana demana "cien gramos de ese queso de gusanos" (roquefort) que passa a "tres unces d'aquell formatge... que camina sol" i, com que en demana poc, el dependent comenta "a pocos gusanos tocarán" > "a pocs estadants sortiran per barba";

b) quan la señá Patro (Munda), la criada Cirila (Quiteria) i Bibiano (Patufa) decideixen descobrir la traïció de Leoncio (Enric) i la señá Asunción (Teresita) contra Nemesio (Quim), la Patro li demana a Bibiano si pot comptar amb ell i aquest li contesta que "de mí dispone usté hasta pa ponerme de felpudo d'un estanco" > "fins per posar-me de ninot mecànic en el aparador";

c) la criada Cirila (Quiteria) li diu a Bibiano (Patufa) que s'ha emportat el got amb l'aigua enverinada abans que la señorita Maravillas (Esperanceta) se'l begués; en aquest moment es desenvolupa entre els dos un diàleg humorístic: Cirila "¡Ahí dentro está la muerte!”, Bibiano “ ¡La muerte!”, Cirila "Pruebe usté y verá”, Bibiano "¡Yo qué voy a probar, miá ésta!", Cirila "Yo decía un sorbito naa más... A ver cómo le sienta", Bibiano "Pero ¿cómo me va a sentar la muerte? ... ¡Muy mal! ¿Usté ha visto a nadie que se muera y engorde?" > Quiteria "Aquí dintre hi ha la mort!", Patufa "La mort!", Quiteria "Provi-ho i veurà", Patufa "I jo... per què ho tinc de provar-ho?", Quiteria "Només un glopet. A veure si sent pessigolles", Patufa "La mort fa pessigolles? $\mathrm{Ca}$, barret... Vostè ha vist a ningú que mori i rigui? Això és un veneno desconegut que pot fer-me molt mal", Quiteria "I si fos conegut, de segur que també n'hi faria!"; etc. 


\subsubsection{REALIA}

Els realia presents en el text de partida experimenten un tractament variat en la seva adaptació, degut a la seva funció estratègica a l'hora d'apropar el text al nou públic al qual va dirigit.

\subsubsection{Realia adaptats}

a) Leoncio (Enric) i Maravillas (Esperanceta) li proposen a Nemesio (Quim) que ells i Asunción (Teresina) vagin al teatre i la noia fa referència a un espectacle que estan representant "en Novedades" > "al Victòria";

b) un diumenge, un parroquià es presenta a la porta de la botiga tancada i li demana al dependent Sisinio (Papitu) "un frasco de caldo Maggi" (una "pastilla" en la versió catalana) i aquest li contesta "que le pongan un puchero" > "un plat d'escudella, que així tindrà gallina i carn per a rosegar una estona i no empipar a ningú"; etc.

\subsubsection{Realia afegits}

El señor Liborio (Llibori) calcula quants diners té per tractar de salvar Nemesio (Quim) del fracàs; s'adona que tan sols té divuit pessetes i Bibiano (Patufa) comenta “¡Pa comprarse una bufanda de dos caras, sí tiene usté; pero, vamos, pa favorecer a un amigo!..." > "Això serveix per un dinar sense propina a l'Exposició, però no per salvar a un amic"; etc.

\subsubsection{Realia eliminats}

La señorita Maravillas (Esperanceta) veu Bibiano (Patufa) i la criada Cirila (Quiteria) abraçats, mentre tracten d'animar-se i trobar el valor per a defensar els seus amos de la traïció que està tenint lloc i pensa que els dos s'estimen; llavors afirma "estas expansiones son pa la Bombilla; es decir, pa la Bombilla cuando se haya fundido", amb un joc verbal entre el nom del dancing i l'objecte, que en català es perd: "aquestes expansions deixeu-les per quan surti la lluna i la tapin els núvols", mantenint l'allusió al concepte a oscuras; etc.

\subsubsection{MODISMES/FRASES FETES}

a) La señorita Maravillas (Esperanceta) afirma que "Desde que murió mi madre $[\ldots]$, en esta casa, $[\ldots]$, no se han sacao los pies de la manta" > "D'ançà que va morir la pobra mare, $[\ldots]$ aquesta casa ha anat desenrotllant-se en una vida d'anar fent i sortir del pas";

b) Bibiano (Patufa) tracta d'abraçar Sisinio (Papitu) amb dos manats de llonganisses, aquest l'aparta dient "y, además, ésos (por los salchichones) son de Vich!" > "el sotrac que sent al cor no el vull sentir a l'esquena"; etc. 


\subsubsection{JOCS VERBALS}

Arniches aprofita sovint els jocs verbals per produir l'efecte humorístic desitjat. A l'hipertext aquest tret es manté o bé es modifica o fins i tot s'amplifica (amb la introducció de jocs verbals que no apareixien a l'original) o s'eliminen.

\subsubsection{Jocs verbals mantinguts}

Bibiano explica que li han donat una propina quan ha "llevao los pedidos a don Enrique Díaz y a don Antonio Díaz, y como dan un real cada Díaz... que son muy buenos Díaz..."; en la versió catalana, Patufa diu que ha "portat els pedidos a don Enric Dies i a don Antoni Dies i com que són molt bon Dies..."; etc.

\subsubsection{Jocs verbals adaptats}

a) El dependent Sisinio (Papitu) espera la seva xicota Emerenciana (Emetèria) dins la botiga tancada; quan aquesta arriba, li diu “¡Espérate, que te voy a levantar el cierro! ¡Entra, cierro mío... digo cielo mío! (Abre y entra. Se restablece la luz en la tienda y queda ya durante el acto)" > "espera't que aixequi la porta i que la llum dels teus ulls electrifiqui la botiga (Obre i entra. Es restableix la llum en l'establiment $i$ es queda així fins finir l'acte)"; l'adaptador no pot mantenir en català el joc verbal de l'hipotext i s'inspira en l'acotació per a crear-ne un altre;

b) Bibiano (Patufa) i la criada Cirila (Quiteria) volen comprovar si el got d'aigua que li han llevat a la señorita Maravillas (Esperanceta) està enverinat i li demanen al dependent Sisinio (Papitu) que en begui un glopet, dient-li: Bibiano "Tú que eres de Piedra... de Piedrahita, ¿tendrías inconveniente de probar el agua de este vaso, a ver qué te sabe?", aprofitant el joc verbal entre l'objecte i el topònim; això s'adapta en la versió catalana: Patufa "tu que ets de Tremp i ets més fort que el ferro trempat: vols provar l'aigua d'aquest got a veure què et sembla?"; etc.

\subsubsection{Jocs verbals afegits}

Un dependent ajuda un altre a recordar el nom d'una parroquiana: "la señá Escola”; el segon li contesta: "¡Ah, sí [...] no m’acordaba" > "la senyora Escola”, "Escola de qué?", "Escola de burros, com més gran més papanates et tornes", "Ah, sí! Ara me'n recordo", joc verbal possibilitat pel significat del terme escola en català; etc.

\subsubsection{Jocs verbals perduts}

Arriba Emerenciana (Emetèria), la núvia del dependent Sisinio (Papitu), per anar a ballar amb ell, i li diu "Estreno traje. Hechura sastre, color veis. ¿Te gusta?"; ell li contesta "Mucho; pero pa ser veis, la falda me se hace un poco larga" i ella "Es que si me la hago más corta, me siento y veis demasiado" > "Trajo corte sastre. T'agrada?", "Ja ho crec, sobretot aquestes faldilletes que em descobreixen unes coses...", "Apa, estigues quiet!", "És que volia seguir descobrint per veure si arribava a les Pampes", ja que no es pot reproduir el joc verbal amb el verb veis que apareix en l'hipotext; etc. 


\subsubsection{EQUÍVOCS}

La neboda d'una parroquiana arriba a la botiga i demana un paquet de cafè encarregat per la seva tia; el dependent li demana "¿qué lleva tu tía" i la noia contesta "mantón de lana"; llavors ell precisa "¿qué clase de café" i la noia respon "moka" > "com és", "Rosa, amb anells", "pregunto que com és el café", "moquis".

\subsubsection{ACUDITS}

Nemesio (Quim) está fent comptes; arriba una parroquiana avinent i es distreu, llavors afirma "no multiplico" > "els números em surten a glops i tots els erro"; etc.

\subsubsection{DEFORMACIÓ, ÚS IMPROPI I CREACIÓ DE CULTISMES/ ESTRANGERISMES}

3.3.10.1. Ús impropi/creació d'expressions/neologismes cultes/rebuscats/inconseqüents

L'ús o la creació d'expressions o bé de neologismes cultes, rebuscats o inconseqüents caracteritzen en particular la parla d'un dels personatges, el señor Liborio (Llibori): els gèneres alimentaris que es venen en la botiga són "baratijas alimenticias" $i$ en català "menudències alimentoses" $i$ les fulles del calendari són les "hojas almanaqueñas", expressió que es perd en l'hipertext ("Mira la fulla del calendari”); etc.

\subsubsection{2. Ús impropi/deformació d'extrangerismes}

És aquest el tret més típic de la manera d'expressar-se del señor Liborio (Llibori), tant en l'hipotext com en l'hipertext; els exemples d'aquest tipus sovintegen en la peça original castellana i es mantenen en la seva adaptació catalana:

a) "Mira la hoja almanaqueña [...] instalada en ese buró (francés) y sus dos guarismos aritméticos te dirán a priori (latín) el objetivo de mi interviú (inglés) con más elocuencia que un orador de los que están en mutis (esperanto)", formes que també apareixen en l'hipertext (bureau amb grafia francesa);

b) el señor Liborio sospita que Nemesio (Quim), a la vora del fracàs, es vol suïcidar d'un tret, s'espanta i li diu a Bibiano (Patufa) "No m'acongojes más, por tu madre; mira cómo estoy (le da la mano)" i el noi li contesta "(le toca) ¡Helao!" i l'altre "Frapé, italiano; digo, no, francés... ¡Rediez, que me se están olvidando ya los idiomas!' $>$ Llibori "No em neguitegis més, pel que més vulguis, que mira com estic! (li dóna la $m a ̀)$ ", Patufa "(el toca) Gelat", Llibori "Frapé, italià; dic... francés. Redimontri, que fins confonc els idiomes!";

c) la torbació d'aquest personatge es mostra de forma humorística, com quan tracta de convèncer la señora Patro que li presti diners a Nemesio i allega "voy a ver 
si lo logro, cálamo currente..., inglés, francés, latín... ¡Naa, que he perdío hasta el poliglotismo" > "Provaré [...]. Si ho logro, cálamo currente... anglès, francés, llatí... Res, que he perdut el poliglotisme!"; etc.

\section{CONCLUSIÓ}

De l'anàlisi comparativa entre l'hipotext i l'hipertext s'infereix l'existència de dos macroàmbits en les estratègies d'adaptació. El primer es relaciona amb l'aclimatació del text de partida al context d'arribada i alhora al "convencionalisme" d'Arniches, és a dir al fet que els seus personatges s'expressen com si fossin gent del poble, tot i concretant un popularisme antimimètic, típic del seu sistema lingüístic original i creatiu. El segon macroàmbit és representat per la dislocació expressiva, o sigui la deformació de paraules i expressions amb finalitat humorística.

El tret fonamental de la primera categoria és la pèrdua del madrilenyisme lingüístic, encara que es conservin prou castellanismes emfatitzats gràficament. Aquest és un aspecte clau de l'hipertext i del context/públic específic a què va dirigit: en la versió catalana, aquests mecanismes d'adaptacions són possibles gràcies al bilingüisme que caracteritza l'àmbit d'arribada. A tot això se sumen altres aspectes, com ara l'adaptació de topònims, antropònims i realia al context dels receptors. En la segona categoria es poden classificar trets deformants derivats de la finalitat humorística de l'obra, que originen un conjunt prou ric de mecanismes que es mantenen en l'hipertext. Entre ells, els més rellevants són la deformació de prèstecs i estrangerismes o de modismes o bé de cultismes i l'ús hiperemfâtic de diminutius, jocs verbals, acudits i equívocs.

En fi, una operació reeixida que, a partir d'un hipotext que va obtenir un gran èxit, aconsegueix transposar-ne eficaçment els components de gran efectisme humorístic $i$ alhora emotiu. L'hipertext, tot i la pèrdua de la matisació bàsica del text de partida (el madrilenyisme), a la qual és condemnat tot procés d'adaptació d'un model lingüísticament connotat de forma tan marcada i específica, manté intactes totes les característiques de l'original: el popularisme antimimètic en totes les seves declinacions i els mecanismes humorístics, dels quals aconsegueix mantenir tota la riquesa $i$ varietat.

\section{AGRAÏMENTS}

Aquest treball s'inscriu dins el projecte d'investigació del Ministerio de Ciencia e Innovación FFI2017-86542-P titulat La literatura de segundo grado: las relaciones hipertextuales en la literatura catalana desde el "Modernisme" hasta 1939. Més informació sobre l'activitat del grup investigador a: http://www.uv.es/ironialitcat/. 


\section{REFERÈNCIES BIBLIOGRÀFIQUES}

Arniches, C. (1926). El último mono o El chico de la tienda, sainete en tres actos. Madrid: Prensa Moderna. Arniches, C. (1930). L'adroguer del carrer Nou. Sainet en tres actes (adapt. al català d'A. Pejoan). La Escena Catalana, 328, 1-28.

Arniches, C. (2010). Del Madrid castizo. Sainetes (ed. de J. Montero Padilla). Madrid: Cátedra.

Bacardí, M. (2010). La traducció del català al castellà al segle XX. Esbós d'una història accidentada. Visat. Revista digital de traducció del PEN català, 9, 1-9. Recuperat de http://www.visat.cat/articles/cat/20/ la-traduccio-del-castella-al-catala-al-segle-xx.esbos-duna-historia-accidentada.html.

Díez-Canedo, E. (1926, 11 de novembre). Información teatral: Centro. El último mono o El chico de la tienda, sainete en tres actos de D. Carlos Arniches. El Sol, p. 8.

Fernández Almagro, M. (1948). Entorno al 98. Politica y literatura. Madrid: Jordán.

Floridor [pseud.] (1926, 11 de novembre). Informaciones y Noticias Teatrales: El último mono o el chico de la tienda. $A B C$, s.p.

Gallén, E. (2001). Traduir i adaptar teatre a Catalunya (1898-1938). Dins L. Pegenaute (ed.), La traducción en la Edad de Plata (p. 49-74). Barcelona: PPU.

Larios de Medrano, J. (1926, 11 de novembre). Teatros. El Liberal, p. 3.

Lentzen, M. (1966). Carlos Arniches. Vom "género chico" zur "tragedia grotesca". Ginebra \& París: Librairie Droz \& Librairie Minard.

López Estrada, F. (1943). Notas del habla de Madrid. El lenguaje en una obra de Carlos Arniches. Cuadernos de Literatura Contemporánea, 2, 261-272.

Mayral, J. L. (1926, 11 de novembre). Los estrenos de anoche. La Voz, p. 2.

M. F. A. (1926, 11 de novembre). Veladas teatrales. La Época, p. 1.

Monleón, J. (1967). Arniches: la crisis de la Restauración. Dins C. Arniches, La señorita de Trevélez. La heroica villa. Los milagros del jornal (p. 31-51). Madrid: Taurus.

Montero Padilla, J. (2010). Introducción. Dins C. Arniches (2010), Del Madrid castizo. Sainetes (p. 9-48). Madrid: Cátedra.

Osimo, B. (2004). Manuale del traduttore. Milà: Hoepli.

Paco, M. de (1994). Comicidad y crítica social en el teatro de Carlos Arniches. Biblioteca Virtual Miguel de Cervantes. Recuperat de http://www.cervantesvirtual.com/obra-visor/comicidad-y-crtica-social-en-el-teatro-de-arniches-del-madrid-castizo-y-la-heroica-villa-0/html/00fc2252-82b2-11df-acc7002185ce6064_4.html.

Pérez de Ayala, R. (1966). Obras completas, III. Madrid: Aguilar.

Portillo, E. M. del (1948). Carlos Arniches. El hombre. El autor. Dins C. Arniches, Teatro completo, I (p. 11-30). Madrid: Aguilar.

Ramos, V. (1966). Vida y teatro de Carlos Arniches. Madrid \& Barcelona: Alfaguara.

Ríos Carratalá, J. A. (2003). Arniches y el teatro cómico. Dins J. Huerta Calvo (coord.), Historia del teatro español, II: Del siglo XVIII a la época actual (p. 2393-2418). Madrid: Gredos.

Ríos Carratalá, J. A. (2006a). Carlos Arniches. Biblioteca Virtual Miguel de Cervantes. Recuperado de http://www.cervantesvirtual.com/obra/carlos-arniches-1/.

Ríos Carratalá, J. A. (2006b). Carlos Arniches. Bibliografía. Biblioteca Virtual Miguel de Cervantes. Recuperado de http://www.cervantesvirtual.com/obra/carlos-arniches-bibliografia--0/.

Ríos Carratalá, J. A. (2008). Los autores y las obras. La tradición sainetesca. Arniches. Dins J. Huerta Calvo (coord.), Historia del teatro breve en España (p. 993-1022). Madrid \& Frankfurt am Main: Iberoamericana \& Vervuert.

Ruiz Ramón, F. (2011). Historia del teatro español. Siglo XX. Madrid: Cátedra.

Salinas, P. (1949). Literatura española. Siglo XX. Mèxic: Antigua Librería Robredo.

Seco, M. (1970). Arniches y el habla de Madrid. Madrid: Alfaguara. 
Senabre, R. (1967). Creación y deformación en la lengua de Arniches. Segismundo. Revista Hispánica de Teatro, 4, p. 247-277.

Sotomayor Saéz, M. V. (1998). Teatro, público y poder. La obra dramática del último Arniches. Madrid: Ediciones de la Torre.

Vilches de Frutos, M. F. \& Dougherty, D. (1997). La escena madrileña entre 1926 y 1931. Un lustro de transición. Madrid: Fundamentos.

Villa, A. de la (1926, 11 de novembre). Los teatros: Centro. La Libertad, p. 4.

Vlahof, S. \& Flori, S. (2019). La traduzione dei realia. Saggio sulla resa delle parole culturospecifiche (ed. de L. Lipani \& B. Osimo). Milà: Bruno Osimo Editore. 